\title{
Communication \\ CP12 Is Involved in Protection against High Light Intensity by Suppressing the ROS Generation in Synechococcus elongatus PCC7942
}

\author{
Masahiro Tamoi ${ }^{1,2, *}$ and Shigeru Shigeoka ${ }^{3}$ \\ 1 Department of Advanced Bioscience, Faculty of Agriculture, Kindai University, 3327-204 Nakamachi, \\ Nara 631-8505, Japan \\ 2 Agricultural Technology and Innovation Research Institute, Kindai University, 3327-204 Nakamachi, \\ Nara 631-8505, Japan \\ 3 The Experimental Farm, Kindai University, 2355-2 Yuasa, Yuasa-cho, Arida-gun, Wakayama 643-0004, Japan; \\ shigeoka@nara.kindai.ac.jp \\ * Correspondence: tamoi@nara.kindai.ac.jp; Tel.: +81-742-43-8196
}

Citation: Tamoi, M.; Shigeoka, S. CP12 Is Involved in Protection against High Light Intensity by Suppressing the ROS Generation in Synechococcus elongatus PCC7942. Plants 2021, 10, 1275. https://doi.org/ $10.3390 /$ plants10071275

Academic Editors: Tomoko Shinomura and Shun Tamaki

Received: 22 May 2021

Accepted: 21 June 2021

Published: 23 June 2021

Publisher's Note: MDPI stays neutral with regard to jurisdictional claims in published maps and institutional affiliations.

Copyright: (c) 2021 by the authors. Licensee MDPI, Basel, Switzerland. This article is an open access article distributed under the terms and conditions of the Creative Commons Attribution (CC BY) license (https:// creativecommons.org/licenses/by/ $4.0 /)$.

\begin{abstract}
We previously reported that CP12 formed a complex with GAPDH and PRK and regulated the activities of these enzymes and the Calvin-Benson cycle under dark conditions as the principal regulatory system in cyanobacteria. More interestingly, we found that the cyanobacterial CP12 gene-disrupted strain was more sensitive to photo-oxidative stresses such as under high light conditions and paraquat treatment. When a mutant strain that grew normally under low light was subjected to high light conditions, decreases in chlorophyll and photosynthetic activity were observed. Furthermore, a large amount of ROS was accumulated in the cells of the CP12 gene-disrupted strain. These data suggest that CP12 also functions under light conditions and may be involved in protection against oxidative stress by controlling the flow of electrons from Photosystem I to NADPH.
\end{abstract}

Keywords: CP12; cyanobacteria; photo-oxidative stress; photosynthesis

\section{Introduction}

Oxygenic photosynthesis by plants, algae, and cyanobacteria converts sunlight into chemical energy, essential for their metabolism. The Calvin-Benson cycle is the primary pathway for reducing $\mathrm{CO}_{2}$ into biomass; therefore, the control of this cycle in response to environmental changes or the developmental stage is indispensable for photosynthetic organisms. In the Calvin-Benson cycle, the activities of thiol-modulated enzymes, such as $\mathrm{NADP}^{+}$-glyceraldehyde-3-phosphate dehydrogenase (GAPDH), fructose1,6-bisphosphatase (FBPase), sedoheptulose-1,7-bisphosphatase (SBPase), and phosphoribulokinase (PRK), are activated by the reduction of intramolecular disulfide bridges via the ferredoxin/thioredoxin ( $\mathrm{Fd} / \mathrm{Trx})$ system during the day $[1,2]$. When these cysteine residues of the four enzymes are oxidized to form a disulfide bond, they change to the inactive form during the night. The Fd/Trx system is one of the best characterized regulatory mechanisms in plants.

On the other hand, it has been clarified that the enzymes constituting the cyanobacterial Calvin-Benson cycle are not regulated by the Fd/Trx system, unlike those derived from higher plants [3]. These cyanobacterial enzymes lack the cysteine residues required for activity control or the different structures near the cysteine residues [4-8]. Instead, the small protein $\mathrm{CP} 12$ binds to GAPDH and PRK and regulates the activities of these enzymes in response to changes in intercellular $\mathrm{NAD}(\mathrm{P}) \mathrm{H} / \mathrm{NAD}(\mathrm{P})$ levels under light and dark conditions. It was reported that carbon metabolism could be regulated through controlling the activity of these enzymes by associating/dissociating a complex in cyanobacteria [9]. In fact, the cyanobacterial CP12 gene-disrupted strain (Sc $\Delta \mathrm{CP} 12)$ grew normally under constant light conditions, but GAPDH and PRK activities could not be controlled under 
light and dark conditions and showed growth retardation because of abnormal carbon metabolism [9]. From these results, it was clarified that CP12 plays an important role in controlling the carbon flow from the Calvin-Benson cycle to the oxidative pentose phosphate cycle. Moreover, by structural-basis analysis, it has been reported that the CP12, GAPDH, and PRK could integrate each other depend on both redox state and $\mathrm{NAD}(\mathrm{P}) \mathrm{H} / \mathrm{NAD}(\mathrm{P})$ levels to regulate carbon metabolism in cyanobacteria [10].

Interestingly, the growth of Sc $\Delta \mathrm{CP} 12$ was clearly slower than wild-type growth under continuous high light conditions. This phenotype cannot be explained by the CP12 function described above; thus, new CP12 functions are expected. In higher plants and algae, multiple $\mathrm{CP} 12$ homologs are present and have unique functions other than controlling the activity of PRK and GAPDH [11-18]. It has been reported that CP12-1 and CP12-2 work cooperatively to regulate photosynthetic ability through controlling protein levels of PRK in mature leaves of Arabidopsis [19]. However, there have been few reports on the association between $\mathrm{CP} 12$ and environmental stress in plants. In the present study, in order to clarify the novel function of $\mathrm{CP} 12$ in cyanobacteria, we analyzed the response to high light in Sc $\Delta \mathrm{CP} 12$ mutants.

\section{Results}

\subsection{The Lack of CP12 Suppressed Growth under High Light Conditions}

The growth rate of Sc $\Delta \mathrm{CP} 12$ mutants was compared with that of wild-type cells under photoautotrophic conditions. It has already reported that $\mathrm{Sc} \Delta \mathrm{CP} 12$ grows like the WT at $40 \mu \mathrm{mol}$ photons $\mathrm{m}^{-2} \mathrm{~s}^{-1}$ in Tamoi et al. 2005 [9]. We reconfirmed that the growth rate of the Sc $\Delta C P 12$ mutant was almost the same as that of wild-type cells under continuous low light conditions at $40 \mu \mathrm{mol}$ photons $\mathrm{m}^{-2} \mathrm{~s}^{-1}$ (Figure 1A). Under continuous low light conditions at $40 \mu \mathrm{mol}$ photons $\mathrm{m}^{-2} \mathrm{~s}^{-1}$, the growth rate of the Sc $\Delta \mathrm{CP} 12$ mutant was almost the same as that of wild-type cells (Figure 1A). Next, we compared the growth rate of both types of cells under continuous high light conditions at $100 \mu \mathrm{mol}$ photons $\mathrm{m}^{-2} \mathrm{~s}^{-1}$. Under these conditions, wild-type cells grew slightly better than when grow at low light conditions. Interestingly, Sc $\Delta \mathrm{CP} 12$ mutant cells grew significantly slower than wild-type cells (Figure 1B).

\subsection{Effect of High Light Treatment on Chlorophyll Contents}

Chlorophyll contents were compared when cells cultured under low light conditions ( $40 \mu \mathrm{mol}$ photons $\mathrm{m}^{-2} \mathrm{~s}^{-1}$ ) until the logarithmic growth phase were transferred to high light conditions ( $500 \mu \mathrm{mol}$ photons $\mathrm{m}^{-2} \mathrm{~s}^{-1}$ ). After $6 \mathrm{~h}$ of high light treatment, the amount of chlorophyll in the wild strain was reduced to $84 \%$ of that before the treatment. On the other hands, in Sc $\triangle \mathrm{CP} 12$ cells, the amount of chlorophyll decreased to $45 \%$ and $27 \%$ after the high light treatment for 3 and $6 \mathrm{~h}$, respectively, of that before the treatment (Figure 2).

\subsection{Effect of High Light Treatment on Photosynthetic Activity}

The rates of $\mathrm{NaHCO}_{3}$-dependent $\mathrm{O}_{2}$ evolution in wild-type and Sc $\Delta C P 12$ cells under low light $\left(40 \mu \mathrm{mol}\right.$ photons $\left.\mathrm{m}^{-2} \mathrm{~s}^{-1}\right)$ illumination were $86.3 \pm 1.15$ and $85.8 \pm 1.33 \mu \mathrm{mol} \mathrm{h}^{-1}$ (mg chlorophyll $)^{-1}$, respectively; that is, the former was almost the same as the latter. After high light $\left(200 \mu \mathrm{mol}\right.$ photons $\left.\mathrm{m}^{-2} \mathrm{~s}^{-1}\right)$ treatment, the rates of $\mathrm{NaHCO}_{3}$-dependent $\mathrm{O}_{2}$ evolution of wild-type cells decreased to $86 \%$ and $80 \%$ at 4 and $5 \mathrm{~h}$ after the treatment, respectively, while that of Sc $\Delta \mathrm{CP} 12$ cells decreased to $60 \%$ and $40 \%$ at the same duration (Figure 3). 
A

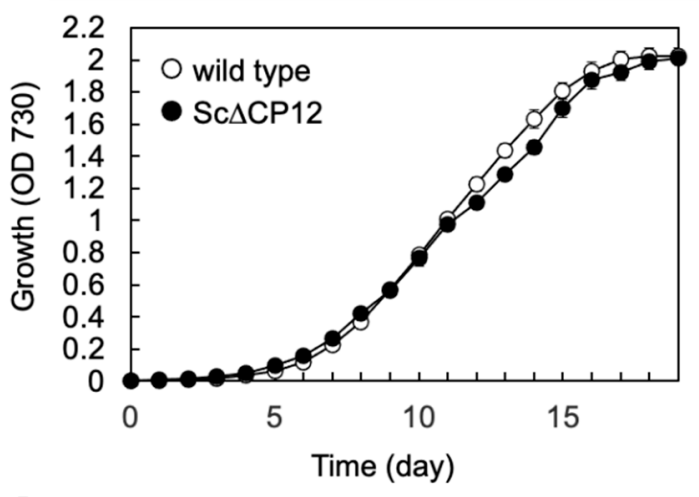

B

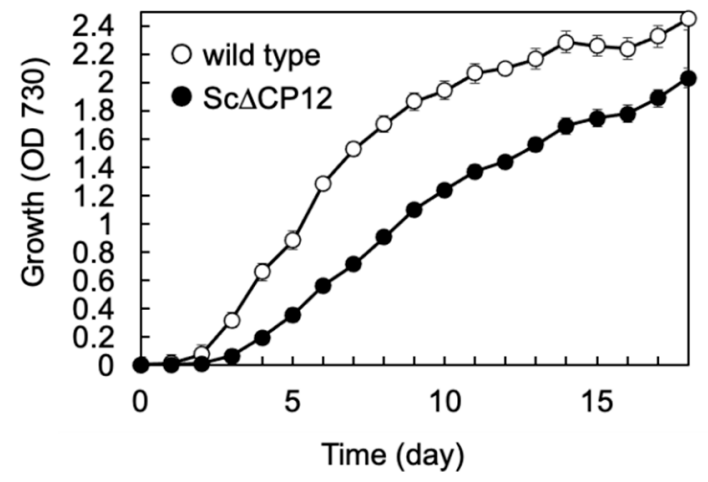

Figure 1. The time-course of photoautotrophic growth of wild-type and Sc $\Delta \mathrm{CP} 12$ mutant $S .7942$ cells under continuous light conditions. Wild-type and $\mathrm{Sc} \Delta \mathrm{CP} 12$ mutant $S .7942$ cells were cultured in $1 \mathrm{~L}$ of Allen's medium at $27^{\circ} \mathrm{C}$ under continuous illumination (A): $40 \mu \mathrm{mol} \mathrm{s}^{-1} \mathrm{~m}^{-2},(\mathbf{B}): 100 \mu \mathrm{mol} \mathrm{s}^{-1} \mathrm{~m}^{-2}$ ) with bubbling of sterile air at $1 \mathrm{~L} \mathrm{~min}^{-1}$.

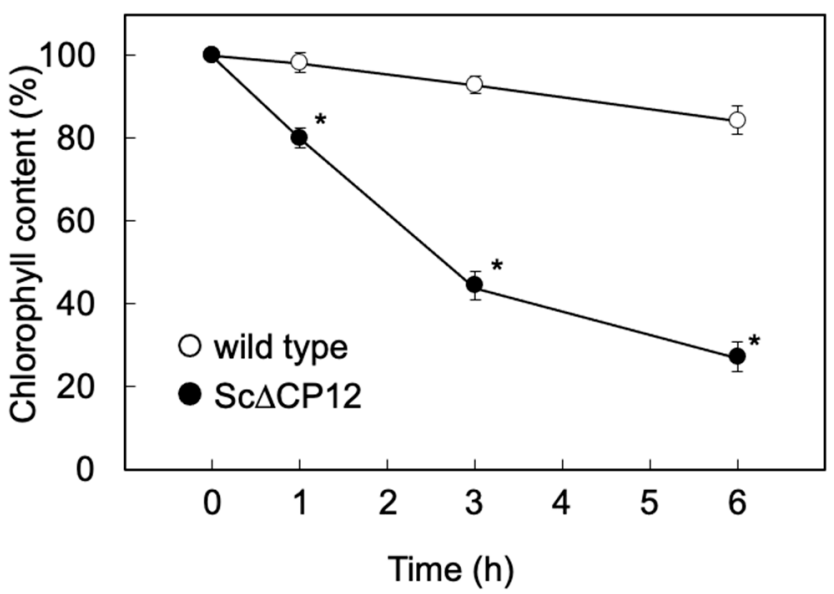

Figure 2. Effect of high-light treatment on the chlorophyll contents in wild-type and Sc $\Delta \mathrm{CP} 12$ mutant S. 7942 cells. Wild-type and Sc $\Delta C P 12$ mutant $S .7942$ cells were cultured in $1 \mathrm{~L}$ of Allen's medium at $27^{\circ} \mathrm{C}$ under continuous illumination $\left(40 \mu \mathrm{mol} \mathrm{s}^{-1} \mathrm{~m}^{-2}\right)$ with bubbling of sterile air at $1 \mathrm{~L} \mathrm{~min}^{-1}$ until the logarithmic growth phase, and then transferred to continuous illumination $\left(500 \mu \mathrm{mol} \mathrm{s}{ }^{-1} \mathrm{~m}^{-2}\right)$. Values are as the mean \pm standard error of four individual experiments. Asterisks indicate significant differences from the wild-type cells $\left.{ }^{*} p<0.01\right)$. 


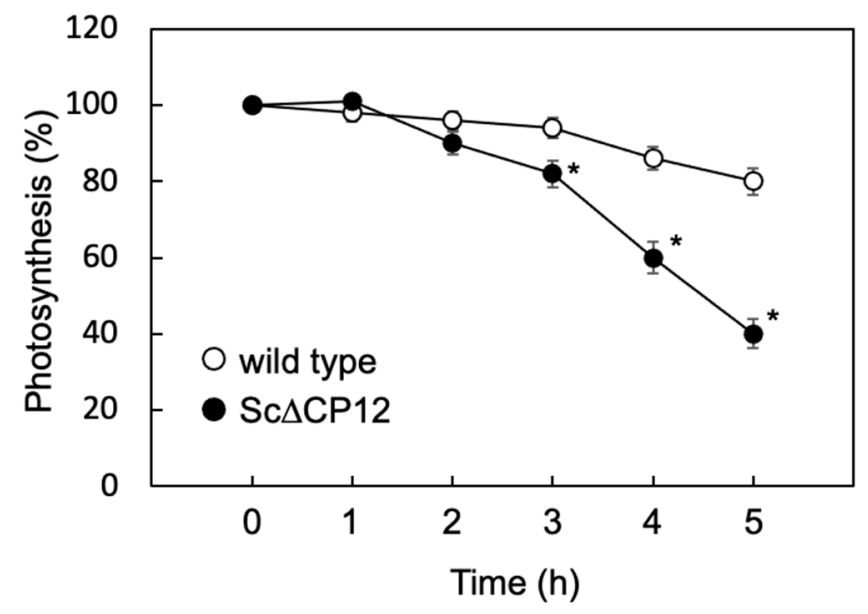

Figure 3. Effect of high-light treatment on the photosynthetic activity in wild-type and Sc $\Delta \mathrm{CP} 12$ mutant $S .7942$ cells. Wild-type and Sc $\Delta$ CP12 mutant $S .7942$ cells were cultured in $1 \mathrm{~L}$ of Allen's medium at $27^{\circ} \mathrm{C}$ under continuous illumination $\left(40 \mu \mathrm{mol} \mathrm{s} \mathrm{m}^{-1}\right)$ with bubbling of sterile air at $1 \mathrm{~L} \mathrm{~min}^{-1}$ until the logarithmic growth phase, and then transferred to continuous illumination $\left(200 \mu \mathrm{mol} \mathrm{s}^{-1} \mathrm{~m}^{-2}\right)$. Changes in the oxygen evolution rate during incubation in the presence of $1 \mathrm{mM} \mathrm{NaHCO}_{3}$ under $100 \mu \mathrm{mol} \mathrm{s}^{-1} \mathrm{~m}^{-2}$ were measured using an oxygen electrode chamber, as described in Experimental Procedures. Values are the mean \pm standard error of four individual experiments. Asterisks indicate significant differences from wild-type cells $\left({ }^{*} p<0.01\right)$.

\subsection{Effect of High Light Treatment on Intercellular ROS Level}

To determine whether the inhibition of growth in Sc $\triangle C P 12$ cells was due to photooxidative stress, the level of intercellular ROS was measured by a ROS-specific reagent (Figure 4). There were no marked differences in ROS levels between wild-type and Sc $\Delta C P 12$ cells before high light treatment. After high light $\left(200 \mu \mathrm{mol}\right.$ photons $\left.\mathrm{m}^{-2} \mathrm{~s}^{-1}\right)$ treatment, ROS levels of wild-type cells increased 2.4-, 3.8-, and 5.6-fold at 1, 4, and $8 \mathrm{~h}$ after stress treatment, respectively, while that of Sc $\triangle \mathrm{CP} 12$ cells increased 3.0-, 5.9-, and 9.8-fold with the same duration. At $3 \mathrm{~h}$ after high light treatment, the ROS level in Sc $\Delta C P 12$ cells was 3.1-fold higher than that in wild-type cells.

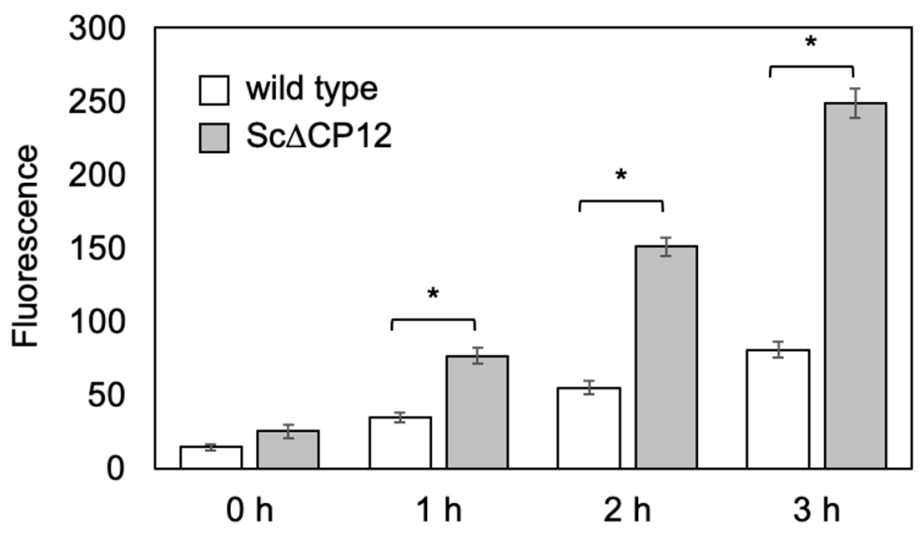

Figure 4. Intercellular ROS levels in wild-type and Sc $\Delta C P 12$ mutant $S .7942$ cells under high light conditions. Wild-type and Sc $\Delta C P 12$ mutant $S .7942$ cells were cultured in $1 \mathrm{~L}$ of Allen's medium at $27^{\circ} \mathrm{C}$ under continuous illumination $\left(40 \mu \mathrm{mol} \mathrm{s}^{-1} \mathrm{~m}^{-2}\right)$ with bubbling of sterile air at $1 \mathrm{~L} \mathrm{~min}^{-1}$ until the logarithmic growth phase, and then transferred to continuous illumination $\left(200 \mu \mathrm{mol} \mathrm{s}{ }^{-1} \mathrm{~m}^{-2}\right)$. Intercellular ROS levels were measured as described in the Materials and Methods. Values are the mean \pm standard error of four individual experiments. Asterisks indicate significant differences from the wild-type cells $\left({ }^{*} p<0.01\right)$. 


\subsection{Effect of Paraquat Treatment on Growth of Wild-Type and ScDCP12 Mutant Cells}

Paraquat (methyl viologen) is widely used as an electron acceptor of Photosystem I (PSI) and inducer of ROS generation. To assay the effect of paraquat on growth, wildtype and Sc $\triangle \mathrm{CP} 12$ cells were cultured in various concentrations of paraquat and exposed to a low light intensity $\left(40 \mu \mathrm{mol} \mathrm{m} \mathrm{m}^{-2} \mathrm{~s}^{-1}\right)$ for seven days. The Sc $\Delta \mathrm{CP} 12$ cells showed slight chlorosis with $0.1 \mu \mathrm{M}$ paraquat compared with wild-type cells. Growth of the wild strain was inhibited as the concentration of paraquat increased, but more marked growth inhibition was observed in the mutant strain, and the mutant strain could not grow in medium containing more than $0.2 \mu \mathrm{M}$ paraquat (Figure 5).

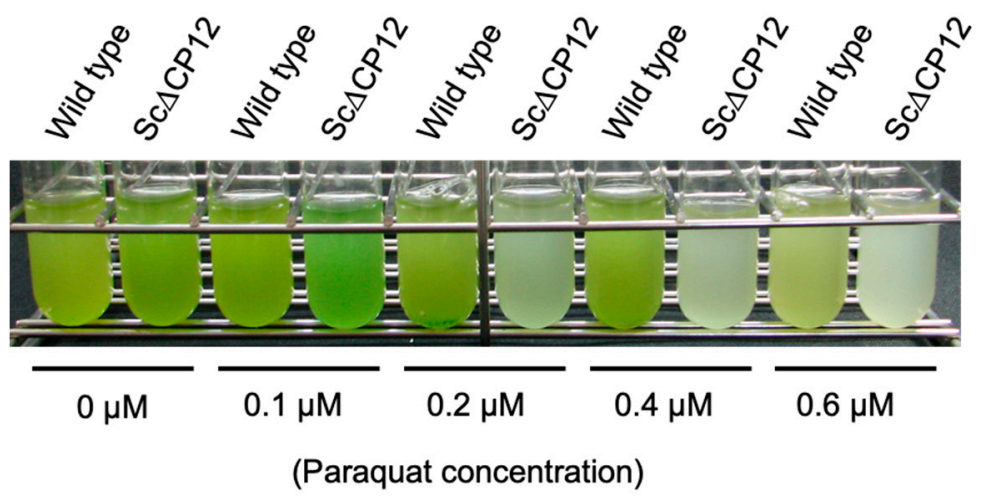

Figure 5. Effect of paraquat treatment on the growth of wild-type and Sc $\Delta C P 12$ mutant $S .7942$ cells. Wild-type and Sc $\Delta C P 12$ mutant $S .7942$ cells were cultured in $10 \mathrm{~mL}$ of Allen's medium containing various concentrations of paraquat on a rotary shaker (120 rpm) under continuous light $\left(40 \mu \mathrm{mol}\right.$ photons $\left.\mathrm{m}^{-2} \mathrm{~s}^{-1}\right)$ at $27^{\circ} \mathrm{C}$.

\section{Discussion}

We previously demonstrated that CP12 formed a complex with GAPDH and PRK and regulated the activities of these enzymes and the Calvin-Benson cycle under dark conditions in cyanobacteria. Moreover, photosynthetic activity of Sc $\triangle \mathrm{CP} 12$ was almost same with that of wild-type under $40 \mu \mathrm{mol} \mathrm{m}{ }^{-2} \mathrm{~s}^{-1}$, suggesting that the lack of CP12 did not affect the capacity of the Calvin-Benson cycle under light condition [9]. Therefore, $\mathrm{CP} 12$ has been considered to work only under dark conditions. Under very weak light conditions, there was no significant difference in the growth of Sc $\Delta \mathrm{CP} 12$ and wild-type cells. When the light intensity was increased, the growth of the wild-type was promoted more than that under the low light condition, but the growth of Sc $\Delta \mathrm{CP} 12$ was clearly lower than that of the wild-type. These data indicate that CP12 must also function under light conditions. As previously reported, the lack of $\mathrm{CP} 12$ did not affect photosynthetic activity in cyanobacteria [9]. These results indicate that the growth of Sc $\Delta \mathrm{CP} 12$ was inhibited without a decrease in photosynthetic activity, suggesting that CP12 plays an important role in the adaptation of photosynthesis to increasing light intensity. In photosynthetic organisms, it is well-known that reactive oxygen species (ROS) accumulate depending on the increase in light intensity, causing oxidative damage [20-22]. In Arabidopsis, it has been reported that $\mathrm{CP} 12$ binds to GAPDH and PRK and protects SH groups involved in regulating the activity of these enzymes from the oxidative state under oxidative stress conditions [23]. However, we previously demonstrated that the activities of GAPDH and PRK were not regulated by the Fd/Trx system via these SH groups in cyanobacteria $[4,7,8]$. Therefore, increased stress sensitivity is not considered to be due to a lack of $\mathrm{SH}$ group-protection ability by $\mathrm{CP} 12$, suggesting the possibility of a novel defense mechanism involving CP12 in cyanobacteria. Moreover, there are no reports that $\mathrm{CP} 12$ deficiency increases susceptibility to oxidative stress in higher plants.

In order to clarify the function of $\mathrm{CP} 12$ to protect against high light conditions, various parameters were compared when cells cultured under low light until the logarithmic growth phase were irradiated with high light. As a result, irradiation with 
$500 \mu \mathrm{mol}$ photons $\mathrm{m}^{-2} \mathrm{~s}^{-1}$ led to a slight decrease in the amount of chlorophyll in the wild-type cells, but a significant decrease in chlorophyll in the Sc $\Delta C P 12$ cells (Figure 2). In addition, to compare the effect of high light stress on photosynthetic capacity, photosynthetic activity was compared. Since the high light treatment at $500 \mu \mathrm{mol}$ photons $\mathrm{m}^{-2} \mathrm{~s}^{-1}$ had too strong an effect on the photosynthetic activity, the photosynthetic activity was compared using cells subjected to high light treatment at $300 \mu \mathrm{mol}$ photons $\mathrm{m}^{-2} \mathrm{~s}^{-1}$. As a result, photosynthetic activity decreased only slightly even after $5 \mathrm{~h}$ of high light treatment in wild-type cells, but it decreased to $40 \%$ after $5 \mathrm{~h}$ of high light treatment in Sc $\Delta \mathrm{CP} 12$ cells (Figure 3). Comparing the amount of intracellular ROS at that time, it was clarified that ROS were significantly accumulated in the $\mathrm{Sc} \Delta \mathrm{CP} 12$ cells as compared with the wild-type cells (Figure 4). It is widely known that under strong light conditions, reactive oxygen species are generated by the surplus photo-reducing power that is not used in the Calvin-Benson cycle and damage the photosynthetic system. However, $100 \mu \mathrm{mol}$ photons $\mathrm{m}^{-2} \mathrm{~s}^{-1}$ of light is never too strong for cyanobacteria. Therefore, it is in a state where active oxygen is more likely to be generated inside Sc $\Delta \mathrm{CP} 12$ cells. Furthermore, when the effects of treatment with paraquat, which is an active oxygen generator, were compared between wild-type and Sc $\Delta C P 12$ cells, significant chlorosis was observed in the Sc $\Delta C P 12$ cells at the lower concentration of paraquat compared with wild-type cells (Figure 5). These data indicate that CP12 deficiency clearly reduces tolerance to photo-oxidative stress. In bacteria and archaea, there are various types of flavodiiron proteins (Flvs) that function as modular enzymes [24]. Some types of Flvs transfer the electrons of NADPH produced in Photosystem I (PSI) to oxygen and produce water without generating ROS, and so they are considered to function in oxidative stress protection in cyanobacteria $[25,26]$. CP12 may be involved in protection against oxidative stress by Flvs, or CP12 may suppress the generation of ROS by controlling the flow of electrons from PSI to NADPH because CP12 protein has the ability to bind to NADPH [9]. At this stage, there is no direct evidence to support this hypothesis, but it is worth further consideration given the emerging new function of CP12 in photosynthetic organisms.

\section{Materials and Methods}

\subsection{Culture Conditions for Synechococcus Elongatus PCC7942}

S. $7942 \mathrm{WT}$ and CP12-deficient mutant (Sc $\Delta \mathrm{CP} 12)$ [9] cells were cultured in $1 \mathrm{~L}$ of Allen's medium at $27^{\circ} \mathrm{C}$ under continuous illumination $\left(40\right.$ or $100 \mu \mathrm{mol}$ photons $\left.\mathrm{m}^{-2} \mathrm{~s}^{-1}\right)$ with the bubbling of sterile air at $8 \mathrm{~L} \mathrm{~min}^{-1}$.

\subsection{Measurement of Photosynthesis and Chlorophyll Contents}

Photosynthesis capacity was determined by measuring the rates of $\mathrm{NaHCO}_{3}$-dependent $\mathrm{O}_{2}$ evolution, as described previously [9]. Cultures in the log phase were washed and resuspended to an OD750 of 0.3 in fresh medium. An aliquot $(1.0 \mathrm{~mL})$ of these samples and $1 \mathrm{mM} \mathrm{NaHCO} 3$ were placed in a DW1 liquid-phase oxygen electrode chamber (Hansatech, Norfolk, UK) and stirred gently at $27^{\circ} \mathrm{C}$ at $100 \mu \mathrm{mol} \mathrm{m} \mathrm{m}^{-2} \mathrm{~s}^{-1}$. The chlorophyll was extracted with acetone and determined content by spectrophotometer as described by Lichtenthaler [27].

\subsection{Measurement of Intercellular ROS Level}

Intercellular ROS levels were determined using the ROS Assay Kit-Highly Sensitive DCFH-DA-(Dojindo, Kumamoto, Japan). An aliquot $(1.0 \mathrm{~m})$ was collected and resuspended with Highly Sensitive DCFH-DA solution and incubated for 30 min under dark conditions, and then placed under 40 or $100 \mu \mathrm{mol}$ photons $\mathrm{m}^{-2} \mathrm{~s}^{-1}$ conditions. Each cell was collected, washed, and resuspended with $100 \mu \mathrm{L}$ of $\mathrm{H}_{2} \mathrm{O}$, and then fluorescence was measured using GroMax Discover System (Promega, Tokyo, Japan) with excitation and emission wavelengths of 475 and $500-550 \mathrm{~nm}$, respectively. 


\title{
4.4. Data Analysis
}

Significance of differences between data sets was evaluated by $t$-test. Calculations were carried out with the Microsoft Excel software.

\begin{abstract}
Author Contributions: Conceptualization, M.T.; methodology, M.T.; formal analysis, M.T.; investigation, M.T.; data curation, M.T.; writing-original draft preparation, M.T.; writing-review and editing, S.S.; supervision, S.S.; project administration, M.T. All authors have read and agreed to the published version of the manuscript.
\end{abstract}

Funding: This research received no external funding.

Conflicts of Interest: The authors declare no conflict of interest.

\section{References}

1. Buchanan, B.B. Role of light in the regulation of chloroplasts enzymes. Ann. Rev. Plant Physiol. 1980, 31, 341-374. [CrossRef]

2. Buchanan, B.B. Regulation of $\mathrm{CO}_{2}$ assimilation in oxygenic photosynthesis: The ferredoxin/thioredoxin system. Arch. Biochem. Biophys. 1991, 288, 1-9. [CrossRef]

3. Tamoi, M.; Murakami, A.; Takeda, T.; Shigeoka, S. The lack of light/dark regulation of enzymes involved in the photosynthetic carbon reduction cycle in cyanobacteria, Synechococcus PCC 7942 and Synechocystis PCC 6803. Biosci. Biotechnol. Biochem. 1998, 62, 374-376. [CrossRef] [PubMed]

4. Tamoi, M.; Ishikawa, T.; Takeda, T.; Shigeoka, S. Enzymic and molecular characterization of NADP-dependent glyceraldehyde3-phosphate dehydrogenase from Synechococcus PCC 7942: Resistance of the enzyme to hydrogen peroxide. Biochem. J. 1996, 316, 685-690. [CrossRef]

5. Tamoi, M.; Ishikawa, T.; Takeda, T.; Shigeoka, S. Molecular characterization and resistance to hydrogen peroxide of two fructose-1,6-bisphosphatases from Synechococcus PCC 7942. Arch. Biochem. Biophys. 1996, 334, 27-36. [CrossRef]

6. Tamoi, M.; Murakami, A.; Takeda, T.; Shigeoka, S. Acquisition of a new type of fructose-1,6-bisphosphatase with resistance to hydrogen peroxide in cyanobacteria: Molecular characterization of the enzyme from Synechocystis PCC 6803. Biochim. Biophys. Acta 1998, 1383, 232-244. [CrossRef]

7. Wadano, A.; Kamata, Y.; Iwaki, T.; Nishikawa, K.; Hirahashi, T. Purification and characterization of phosphoribulokinase from the cyanobacterium Synechococcus PCC7942. Plant Cell Physiol. 1995, 36, 1381-1385. [PubMed]

8. Kobayashi, D.; Tamoi, M.; Iwaki, T.; Shigeoka, S.; Wadano, A. Molecular characterization and redox regulation of phosphoribulokinase from the cyanobacterium Synechococcus sp. PCC 7942. Plant Cell Physiol. 2003, 44, 269-276. [CrossRef] [PubMed]

9. Tamoi, M.; Miyazaki, T.; Fukamizo, T.; Shigeoka, S. The Calvin cycle in cyanobacteria is regulated by CP12 via the $\mathrm{NAD}(\mathrm{H}) / \mathrm{NADP}(\mathrm{H})$ ratio under light/dark conditions. Plant J. 2005, 42, 504-513. [CrossRef] [PubMed]

10. McFarlane, C.R.; Shah, N.R.; Kabasakal, B.V.; Echeverria, B.; Cotton, C.A.R.; Bubeck, D.; Murry, J.W. Structural basis of lightinduced redox regulation in Calvin-Benson cycle in cyanobacteria. Proc. Natl. Acad. Sci. USA 2019, 116, 20984-20990. [CrossRef]

11. Pohlmeyer, K.; Paap, B.K.; Soll, J.; Wedel, N. CP12: A small nuclear-encoded chloroplast protein provides novel insights into higher-plant GAPDH evolution. Plant Mol. Biol. 1996, 32, 969-978. [CrossRef]

12. Wedel, N.; Soll, J.; Paap, B.K. CP12 provides a new mode of light regulation of Calvin cycle activity in higher plants. Proc. Natl. Acad. Sci. USA 1997, 94, 10479-10484. [CrossRef]

13. Wedel, N.; Soll, J. Evolutionary conserved light regulation of Calvin cycle activity by NADPH-mediated reversible phosphoribulokinase/CP12/glyceraldehyde-3-phosphate dehydrogenase complex dissociation. Proc. Natl. Acad. Sci. USA 1998, 95, 9699-9704. [CrossRef]

14. Graciet, E.; Gans, P.; Wedel, N.; Lebreton, S.; Camadro, J.-M.; Gontero, B. The small protein CP12: A protein linker for supermolecular complex assembly. Biochemistry 2003, 42, 8163-8170. [CrossRef] [PubMed]

15. Graciet, E.; Lebreton, S.; Gontero, B. Emergence of new regulatory mechanisms in the Benson-Calvin pathway via proteinprotein interactions: A glyceraldehyde-3-phosphate dehydrogenase/CP12/phosphoribulokinase complex. J. Exp. Bot. 2004, 55, 1245-1254. [CrossRef]

16. Lebreton, S.; Graciet, E.; Gontero, B. Modulation, via protin-protein interactions, of glyceraldehyde-3-phosphate dehydrogenase activity through redox phosphoribulokinase regulation. J. Biol. Chem. 2003, 278, 12078-12084. [CrossRef] [PubMed]

17. López-Calcagno, P.E.; Howard, T.P.; Raines, C.A. The CP12 protein family: Thioredoxin-mediated metabolic switch. Front. Plant Sci. 2014, 5, 9. [CrossRef]

18. Erales, J.; Lignon, S.; Gontero, B. CP12 from Chlamydomonas reinhardtii, a permanent specific "chaperon-like" protein of glyceraldehyde-3-phosphate dehydrogenase. J. Biol. Chem. 2009, 284, 12735-12744. [CrossRef] [PubMed]

19. López-Calcagno, P.E.; Abuzaid, A.O.; Lawson, T.; Raines, C.A. Arabidopsis CP12 mutants have reduced levels of phosphoribulokinase and impaired function of the Calvin-Benson cycle. J. Exp. Bot. 2017, 68, 2285-2298. [CrossRef]

20. Asada, K.; Takahashi, M. Production and scavenging of active oxygen in photosynthesis. In Photoinhibition, 9th ed.; Elsevier: Amsterdam, The Netherlands, 1987; pp. 227-287.

21. Apel, K.; Hirt, H. REACTIVE OXYGEN SPECIES: Metabolism, oxidative stress, and signal transduction. Annu. Rev. Plant Biol. 2004, 55, 373-399. [CrossRef] 
22. Pospíšil, P. Production of reactive oxygen species by photosystem II as a response to light and temperature stress. Front. Plant Sci. 2016, 7, 1950. [CrossRef] [PubMed]

23. Marri, L.; Thieulin-Pardo, G.; Lebrun, R.; Puppo, R.; Zaffagnini, M.; Trost, P.; Gontero, B.; Sparla, F. CP12-mediated protein protection of Calvin-Benson cycle enzymes from oxidative stress. Biochimie 2014, 97, 228-237. [CrossRef] [PubMed]

24. Wasserfallen, A.; Ragettli, S.; Jouanneau, Y.; Leisinger, T. A family of flavoproteins in the domains archaea and bacteria. Eur. J. Biochem. 1998, 254, 325-332. [CrossRef]

25. Allahverdiyeva, Y.; Isojärvi, J.; Zhang, P.; Aro, E.-M. Cyanobacterial oxygenic photosynthesis is protected by flavodiiron proteins. Life 2015, 5, 716-743. [CrossRef] [PubMed]

26. Santana-Sancez, A.; Solymosi, D.; Mustila, H.; Bersanini, L.; Aro, E.-M.; Allahverdiyeva, Y. Flavodiiron proteins 1-to-4 function in versatile combinations in $\mathrm{O}_{2}$ photoreduction in cyanobacteria. eLife 2019, 8, e45766. [CrossRef]

27. Lichtenthaler, H.K. Chlorophylls and carotenoids: Pigments of photosynthetic biomembranes. Methods Enzymol. 1987, 148, 350-382. 